\title{
On Culture Teaching in College English
}

\author{
Li-hong Gu, Fang Liu \\ Foreign Language Teaching Department, Hebei Finance University No.3188, Hengxiang St. Baoding, Hebei Province, China \\ gulihong_2000@163.com
}

\begin{abstract}
This paper begins with the discussion about the definition of language and culture, investigates the current situation of college culture teaching, analyzes the problems that exist from three aspects and puts forward the necessity to cultivate students' intercultural communicative competence and propose some suggestions and strategies to improve culture teaching in college English.

Index Terms - Culture teaching; College English teaching; English culture
\end{abstract}

\section{Introduction}

With the development of economy in China, foreign exchange gets more and more frequent. The economic globalization leads to the urgent need of a great number of talented people who cannot only master the professional knowledge, but also get a good command of English. So the English teaching focused on mere language form cannot meet the requirements of social economic development. Therefore, great importance has been attached to culture teaching in college English, that is because college English teaching aims at imparting language knowledge to students, and the most important is to cultivate students' intercultural communicative competence. Culture teaching is the effective way for the improvement of students' intercultural communicative competence. Language study without cultural background is in vain. So only to improve the culture teaching in college English can we improve students' intercultural communicative competence. This paper is to research on culture teaching among non-English majors, analyze the current situation of cultural teaching, find the problems and put forward strategies and suggestions for culture teaching in the future.

\section{Literature Review}

\section{A. Culture}

Culture is a kind of social phenomenon. Hu Wenzhong said: "culture is created by people's great effort. It is a kind of social heritage, including belief, custom, knowledge, etc. and real objects. " In college English teaching, culture refers to the history, geography, traditional custom, life style, art, literature, code of conduct, social value etc. of a target language. Mastering the culture of a country is beneficial to the understanding and use of a language. Thus it can be seen that students' intercultural communicative ability must be fostered if they want to express in English properly and idiomatically.

\section{B. Language}

Language is the most important tool in social communication. It is a cultural phenomenon, which stands for the image of culture. Language plays a very important role in spreading culture. So it is clear that language and culture cannot be separated from each other.

\section{Relationship between language, culture and English} culture teaching

Language and culture are closely related with each other and influence each other. Language is the carrier of culture and culture is mainly reflected by language. Leaning a language need to know its culture and understanding a country's culture must master its language. Only in this way, can effective intercultural communication be realized. Hu Wenzhong (1994) has ever said: "Language is a form of reflection of language. It is impossible to learn English well without knowing its culture. Language teaching must include culture teaching as well." Therefore, language teaching and culture teaching are closely connected and combined, great importance should be attached to culture teaching in college English to motivate students in learning both Chinese and western culture, cultivate their cultural consciousness, and master cultural difference in order to improve students' intercultural communicative competence.

\section{The Research}

\section{A. Purpose}

The purpose of this study is to know the overall situation of the current college culture teaching. Only knowing about the actual condition of the problems that exist in culture teaching can teachers find the effective methods to improve students' intercultural communicative competence. Therefore this study aims at three questions: 1) the overall situation of the current culture teaching. 2) Why are there some problems in culture teaching and learning? 3) How to solve these problems in culture teaching?

\section{B. Subjects and Instruments}

Subjects of this study are 400 sophomores of non-English majors and 80 English teachers in two universities. All the students have been studying English for more than six years and they come from four different majors; they have cognitive abilities to identify the cultural phenomenon in English learning. Their mother tongue is Chinese and English is a foreign language to them. The instruments involved in this research are questionnaire and interview. All the subjects respond to the questionnaire and participate in the interview.

\section{Procedures}

The study has been conducted in the following steps. The first step is the administration of questionnaire among a small number of teachers and students. The questionnaire involves as many problems as possible in English culture teaching. According to the feedback information of the first 
administration, the questionnaire has been modified, thus to ensure the objectivity and validity of the questionnaire. The content mainly concerns the following aspects: 1 . The current teaching mode in culture teaching, the culture teaching effect, and students' reception and suggestions. The second step is the administration of the modified questionnaire. After that, 396 and 80 questionnaires have been collected. The third step is an interview. After the questionnaire is finished, some students will be interviewed. The interview is to make every student fully display their difficulties in English culture learning. In this way, we can roundly and exactly know the actual situation of the current college English culture teaching and learning. The fourth step is data collection and discussion. In this part, statistical results will be analyzed in terms of the data of the questionnaire and the interview.

\section{The Current Situation and Problems in College English Culture Teaching}

The statistical results show that college English teachers have realized the importance of cultural teaching. But to a great extent, English teaching cannot satisfy the students' need to learn western culture. Though English teachers have begun to introduce culture into English teaching, it is still as an auxiliary and small part of the class. Culture teaching has not been stressed to a great degree. Many students fear that they cannot communicate with the foreigners in English freely and fluently in their future job. In this part, the current situation and problems in culture teaching will be analyzed from the following three aspects: current culture teaching mode, teaching effect and students' reception and suggestion.

\section{A. The Current College Culture Teaching Mode}

It can be seen obviously that teacher-centered classroom teaching still plays a leading role from the actual condition of the college English culture teaching. Statistical results show that 85 percent of English teachers give students a lecture on culture themselves. 40 percent of English teachers collect cultural background knowledge related to the text, and then introduce it to students in class. 40 percent of English teachers assign students to search cultural information after class, and then ask them to present it in class. The shortage is that students cannot collect comprehensive information and their presentations lack of vitality and cannot arouse other students' interest, thus lead to a bad teaching effect. So it can be seen that the current culture teaching mode is single, the pure teacher-centered teaching can only pass a small number of information to students and the lack of interactive activities cannot stimulate students' initiative in learning. It is found that 12 percent of students think emphasis has been laid on culture teaching, 66.8 percent of students think teachers play stress on language points, and some teachers only pass the cultural points over quickly. From the above, we can see that culture teaching has not been paid enough attention to in English teaching. Language teaching has not been closely connected to the cultivation of students' intercultural communicative competence. From the perspective of teachers, although English teachers all majored in English, they have not enough time and energy to be engaged in teaching research due to strenuous teaching tasks, thus leads to such a phenomenon that teachers themselves have a poor foundation of culture and they are lack of intercultural knowledge.

\section{B. students' reception}

20 percent of students who have a weak foundation in English reflect that they cannot concentrate their attention in class. Students are passive listeners and the class atmosphere is not harmonious due to the lack of interactive activities. Teachers always firstly give a lecture to students on text structure and language points. So when it comes to culture learning, students always easy to be distracted in class. Even some students complain that teachers lecture on culture is boring, and then they begin to read other books instead. 71 percent of students do not have a strong consciousness of culture learning, and they only depend on the teachers in class to get cultural information. These students spend most of their time and energy on language form, such as vocabulary, grammar. They believe that mastering language form is the critical part of learning a certain language. 16 percent of students think that culture learning has nothing to do with English level. A small part of students are bored with the present single teaching mode, and they feel they cannot benefit much from English class. It is also found from the investigation that 14.5 percent of students want to get cultural knowledge out of interest, while 59 percent of students think the purpose of their English learning is to pass CET 4 and 6, they learn English in order to pass the exams and are not aware of the importance of culture learning in cultivating students' intercultural communicative competence. Based on the cause analysis, it is mainly because students' interests in culture learning have not been stimulated to a great extent and teachers fail to make students fully understand that intercultural communicative competence is the ultimate goal of language learning.

\section{Culture teaching effect}

The traditional teaching mode is teacher-centered, which makes college English teaching be out of joint with culture teaching and lack of interactive communication between teachers and students. Students generally reflect that they cannot get a good command of the cultural background behind the language form and their autonomous and research-oriented abilities have not been formed. Through interview among teachers, it can be found that teacher is the main body in teaching activity; students only passively accept English culture imparted by teachers. Teachers have not realized that the process of learning is the actively psychological construction. This kind of traditional teaching mode deprives students their opportunity of doing a research and learning something on their own. Most students understand the difference between Chinese and English at the minimum. So there always are misunderstandings and barriers when they communicate in English. Although most students passed CET 4 and 6 , their intercultural communicative ability cannot meet the requirements of the companies. That is to say college 
English teaching stresses the results of the exams.

Another phenomenon is that Chinese culture is also neglected in college English teaching. The main purpose of college English teaching is to improve students' intercultural communicative ability. The communicative ability is not only based on the learning of target language but also closely related to the understanding of Chinese culture because the intercultural communication is a way to learn western culture; the most important is to bring Chinese culture to other countries, making foreigners know Chinese history, custom and social value. Meanwhile, without deep understanding of Chinese culture, students are difficult to resist the bad influence by culture shock.

From the above three aspects we can see that there is no planned, directed culture teaching mode in college English teaching. The problems in culture teaching have to be solved urgently.

\section{The necessity and importance of culture teaching}

From the analysis above, we are clear that foreign language teaching in China only puts emphasis on vocabulary and grammar; students cannot deeply understand the cultural connotation behind the language. There is no obvious direction for culture teaching in the syllabus, so teachers only introduce culture randomly according to their own will. Also culture teaching only concerns the surface of the cultural phenomenon; the deep analysis of a cultural phenomenon has not been involved. Secondly, the current examination-oriented education system hinders the implementation of college culture teaching. CET 4 and 6 are regarded as the main standard to evaluate the quality of college English teaching. Students learn English for exams; college teaching is for exams as well. Thus culture teaching is put into an embarrassing situation. Thirdly, English teachers have a profound knowledge of the language itself, but their cultural accomplishment need to be improved. To sum up, it is necessary and important to change current college culture teaching.

The Ministry of Education has issued new Teaching requirements for college English teaching, where it clearly mentions that the teaching objective of college English is to cultivate students' comprehensive ability to use English, improve their cultural accomplishments in order to meet the need of the society. The curriculum requirements emphasize students' intercultural communicative consciousness and ability. It is obvious that culture teaching becomes increasingly important and compulsory in language teaching and learning. Therefore, culture teaching has to be reinforced and provide students an effective way to understand English culture and the language itself, thus to promote students' language competence.

\section{Suggestions and Strategies to College English Teaching and Learning}

Since we know the importance of culture teaching in college English, both teachers and students should form cultural consciousness. Here some suggestions and strategies are put forward in the perspective of teachers and students.

\section{A. Requirements for Teachers}

1) Change traditional teaching mode and establish a new type of relationship between teachers and students

In traditional college English culture teaching and learning, teachers are only knowledge imparters, while students are passive listeners. With time going on, students' interests in English learning will be ruined. Under such circumstances, it is critical and urgent to change the traditional culture teaching mode. A research-oriented teaching mode which is student-centered is on the way. The new kind of teaching mode is autonomous, open and interesting. The role of teachers and students will change fundamentally. Teachers are not only knowledge imparters, but also exert many other roles like organizers, facilitators, researchers, participants, supervisors and assessors and so on. Students are the main body and focus of the learning process, they transform to active participants, independent thinkers, active knowledge explorers, and evaluators in the learning process. This new teaching mode is helpful for establishing a new kind of relationship between teachers and students and beneficial for cultivating students' initiative and creative spirit. In this way, can students' autonomous learning be improved, thus to improve the quality of college English culture teaching.

2) Reinforce English culture teaching and improve teachers' cultural accomplishments

Culture is the essential part contained in a certain language. Foreign language learners have to get a good command of language forms, more importantly, they have to master the cultural information behind the language. Therefore, teachers have to place emphasis on culture teaching, lead students to pay more attention to the cultural background and cultivate their cultural sensitivity and insight. At the same time, teachers' comprehensive cultural accomplishments have to be improved, and put culture teaching into the whole process of English teaching. So it is necessary to combine culture teaching and language teaching naturally and create a harmonious atmosphere in culture learning. Teachers not only have to be equipped with cultural information of English countries, but also are familiar with their native culture and attach importance to the difference between different cultures. Only in this way can teachers' sensitivity be enhanced and their activity be stimulated.

3) Cultivate students' cultural consciousness, cultural thinking and intercultural communicative ability

In the research-oriented teaching mode, teachers play the roles of guide, director and encourager. Students are the focus of the learning process. So students' learning consciousness and attitude determine the learning effect. In English teaching, teachers have to foster students' insight into culture, fully arouse their initiative and enthusiasm and bring their active cognitive ability into full play, thus to make students experience the happiness in the course of language communication. Meanwhile, teachers can design various cultural and intercultural communicative contexts, such as telling a cultural story, English film appreciation. In these natural and actual language contexts, students can deeply 
experience the communicative function of language and gradually foster an English thinking way. After class, teachers and students can make full use of the internet to get much more information. Based on the teaching material, teachers can help students find some related topics and assign them some tasks, for instance, to have a discussion on the topics they are interested in or prepare an English drama. Only in the real cultural communicative activities can students experience the happiness and fun in culture learning, enhance their cultural consciousness and their intercultural communicative abilities.

\section{B. Requirements for students}

1) Students should give full play to their subjective initiative

The nature of learning lies in the construction of new knowledge based on students' previous knowledge and experience. Teachers play the guiding role in the process of students' knowledge construction. It is the students' subjective initiative that plays a part in this process. Teachers as guiders should have full knowledge of students' present level of culture learning, make students realize the importance of their native culture, experience the difference between Chinese culture and foreign cultures and arouse their interest in learning culture. In this way, students can bring their learning enthusiasm into full play, experience cultural phenomena initiatively and improve their intercultural communicative ability.

\section{2) Read literature works and watch English movies}

Language input is the premise of language acquisition. Literature works and English movies can totally embody a country's culture. So it is essential for students to read literature works extensively. And most students are interested in English movies. Students' enthusiasm for culture learning can be stimulated by excellent movies. Then, there can be a suggestion in English learning, students have to read literature works and watch English movies to catch the cultural factors consciously and selectively. Especially after reading a good novel or watching a good English movie, students can be assigned to prepare a book review to present in class or an English drama to role play the story in the movie. It is beneficial for them to deeply experience foreign culture. And with more practice, students can gradually master the differences and similarities between Chinese culture and English culture.

\section{Conclusion}

All in all, culture learning plays a critical role and determines the success of college English teaching. We should consider culture teaching and learning as important as the acquisition of vocabulary and grammar because they influence each other, facilitate each other. Through research on current culture teaching among non-English majors, we can find clearly the problems in college English teaching. The purpose of college English teaching is to cultivate students' comprehensive ability in language use. Therefore, teachers have to attach great importance to culture, adopt proper teaching strategies and find a student-centered, researchoriented teaching mode to facilitate college English culture teaching. This kind of teaching mode is expected to bring teachers and students' dominant and leading role into full play. In mutual cooperation, culture learning will become a process to improve both teaching and learning. Teachers' authority, students' dependency, and dullness of culture teaching will be replaced totally. On the contrary, students' autonomous learning ability will be cultivated to a great degree. This new research-oriented teaching mode will be further studied in the next paper.

\section{Acknowledgment}

This research is sponsored by the projects in (1)"Excellent Basic Discipline: Foreign Linguistics and Applied Linguistics" in Hebei Finance University and (2) Hebei provincial Party committee lecturer "Research on College English Teaching Mode under the Background of Digital Education".

\section{References}

[1] C. Kramach. "The Culture Component of Language Teaching," Language, Culture and Curriculum, vol. 8, no. 2, pp. 83-92, 1995.

[2] C. Kramach. Context and culture in language teaching. England: Oxford University Press 1995.

[3] Crystal, David, English as a global language, Foreign Language Teaching and Research Press and Cambridge University Press, 2001.

[4] Phillipson, R. Linguistic imperialism, Shanghai Foreign Language Education Press, 2000.

[5] Shrum, J. L. \& Glisan, E. W. Teacher's Handbook; Contextualized Language instruction. Beijing: Foreign Language Teaching and Research Press, 2004.

[6] F Jabeen, S Kazim Shah,. "The Role of Culture in ELT: Learners' Attitude towards the Teaching of Target Language Culture," European Journal of Social Sciences, vol. 23, no. 4, pp. 604-613, 2011.

[7] Z Moore, B Morales, S Carel. "Technology and teaching culture: Results of a state survey of foreign language teachers," Calico Journal, vol. 15, no.1-3, pp. 109-128, 2013. 